\title{
Biofouling impacts and toxicity of Antifouling agents on marine environment: a qualitative study.
}

\section{Impactos de la bioincrustación y toxicidad de los agentes antiincrustantes en el medio marino: un estudio cualitativo.}

\author{
Nithi E Sadan ${ }^{1}$, Akash P S ${ }^{1}$, Sunil Kumar P G ${ }^{2}$ \\ ${ }^{1}$ Student, ${ }^{2}$ Dean (Research) \\ Naval Architecture and Ship Building Engineering \\ Sree Narayana Gurukulam College of Engineering \\ Ernakulam (kerala), India
}

Corresponding author mail id: nithi.sadan@gmail.com, akps2399@gmail.com,snlkmrpg@gmail.com

\begin{abstract}
Biofouling from microorganisms, plants, barnacles, mussels or algae is a major problem for marine structures. Fouling leads to increased fuel costs due to increased frictional resistance on ships, and reduces reserve buoyancy of floating offshore structure, in addition to causing cage deformation and structural fatigue, impacting endurance of materials. The intrusion of invasive aquatic species (IAS) to new environments by ships is identified as a major threat to the world's oceans. Marine fouling affects most manmade surfaces immersed in the sea, resulting in substantial losses. Anti-fouling paints tackle this problem to a certain extent. Extensive research is in progress in the antifouling technologies in maritime sector, with new products in compliance with International Maritime Organisation (IMO) regulations being developed. The most efficient solution to minimise fouling is to make surfaces unsuitable for settlers, coating them with Antifouling (AF) Paints containing toxic compounds. Most AF agents had Tributyltin (TBT), and has been phased out by IMO since 2008 due to harmful effect on environment. However, use of TBT in AF paints is not prohibited, though has been restricted in several countries. The environmental problems by biofouling and toxicity of existing and alternative Anti-Fouling techniques are reviewed in this paper. Further, various ship hull cleaning technologies commercially available including afloat cleaning are also introduced.

Keywords- Biofouling, TBT, Antifouling (AF), IAS, IMO, AFS, Alternatives
\end{abstract}


Sustainability, Agri, Food and Environmental Research, (ISSN: 0719-3726), 10(X), 2022: http://dx.doi.org/

\section{RESUMEN}

La bioincrustación de microorganismos, plantas, percebes, mejillones o algas es un problema importante para las estructuras marinas. El ensuciamiento conduce a mayores costos de combustible debido a una mayor resistencia a la fricción en los barcos y reduce la flotabilidad de reserva de la estructura flotante en alta mar, además de causar deformación de la jaula y fatiga estructural, lo que afecta la resistencia de los materiales. La intrusión de especies acuáticas invasoras (EEI) a nuevos entornos por parte de los barcos se identifica como una gran amenaza para los océanos del mundo. Las incrustaciones marinas afectan a la mayoría de las superficies artificiales sumergidas en el mar, lo que provoca pérdidas sustanciales. Las pinturas antiincrustantes abordan este problema hasta cierto punto. Se está llevando a cabo una amplia investigación en las tecnologías antiincrustantes en el sector marítimo, y se están desarrollando nuevos productos que cumplen con las regulaciones de la Organización Marítima Internacional (OMI). La solución más eficaz para minimizar las incrustaciones es hacer que las superficies no sean aptas para los sedimentadores, recubriéndolas con pinturas antiincrustantes (AF) que contienen compuestos tóxicos. La mayoría de los agentes de FA tenían tributilestaño (TBT) y la OMI los ha eliminado gradualmente desde 2008 debido a sus efectos nocivos sobre el medio ambiente. Sin embargo, el uso de TBT en pinturas AF no está prohibido, aunque se ha restringido en varios países. En este documento se revisan los problemas ambientales por bioincrustación y toxicidad de las técnicas antiincrustantes existentes y alternativas. Además, también se introducen diversas tecnologías de limpieza de cascos de barcos disponibles comercialmente, incluida la limpieza a flote.

Palabras clave: biofouling, TBT, antiincrustante (AF), IAS, IMO, AFS, alternativas

\section{INTRODUCTION}

The marine biofouling is the phenomenon of accumulation of undesirable marine organisms, animals or plants on a submerged surface in seawater. One of the effects of fouling on ships and the environment is an increase of frictional resistance, which leads to the reduction of ship speed. This leads to more fuel consumption to compensate the speed loss. Increased fuel consumption, in turn generates harmful emissions and that is another environmental issue. It has been estimated that uncontrolled fouling in shipping would result in $40 \%$ more power, which equals 72 million tonnes of additional fuel per year (Milne. A., 1990). Anti-fouling system (AFS) have been introduced to overcome the issue of the accumulation of biofouling on ship's hulls. Among all types of solutions, tributyltin self-polishing copolymer paints (TBT-SPC paints) have been the most successful solution to prevent biofouling. The use of TBT-SPC paints had spread widely, covering $70 \%$ of the world fleet. Unfortunately, the TBT-SPC systems have a severe effect on the environment, such as causing 
Sustainability, Agri, Food and Environmental Research, (ISSN: 0719-3726), 10(X), 2022: http://dx.doi.org/

defective shell growth in molluscs and it caused the development of male characteristic in female genitalia. After the Antifouling System convention held in 2001, the state parties banned the application of TBT based anti-fouling paints from January 2003. It was further required to remove its presence from ships' surfaces in 2008. Consequently, the paint industry has been forced to produce TBT-free antifouling-paints which have the same economic benefits and are less harmful to the environment.

\section{BIOFOULING AND ITS IMPACTS}

The term biofouling is defined by IMO as, "the accumulation of aquatic organisms such as micro-organisms, plants, and animals on surfaces and structures immersed in or exposed to the aquatic environment".

The problem of biofouling is as old as navigation itself. From the moment vessels were launched in ancient times, thousands of aquatic organisms found new surfaces to grow on and develop. The adherence of these organisms to ships had several consequences, such as corrosion of ship structures, impacts on manoeuvrability, and reduction of lifespan of ships. This unwanted phenomenon of biofouling has affected ships for hundreds of years, since humanity has been sailing the seas. The set of bio-organisms that grows on submerged structures is composed of hundreds of species such as bacteria, protozoa, algae, molluscs, and hydrozoans, among others. These organisms, which often add up to more than 150 kilograms per square meter adhere firmly to the surface of the hull, growing rapidly and with great potential for reproduction. These damages affect the vessels, oil or gas platforms, research instruments, aquaculture facilities and the cultivated organisms themselves.

The effects produced by biofouling can be approached from three points of view:

a) The toxicity of Antifouling paints: The risk for marine ecosystems when using chemical products such as paints with biocides to eliminate biofouling. By using this type of paint, which contains highly polluting biocides such as TBT; estuaries, bays, seafood extraction areas, and fishing areas are at risk.

b) Ship efficiency, operational and economic problems for the navigation of ships: When the ships have a layer of biofouling on the hull, this produces higher resistance to water, as a result of the friction existing between the dirty hull and the sea or better-called hull-water hull interface. This resistance reduces the speed of the ship and increases fuel consumption while reducing the manoeuvrability of the vessel. This also necessitates more stops for maintenance and cleaning of the hull and all its associated expenses.

c) Environmental risks and the introduction of invasive aquatic species (IAS): Biofouling along with ballast water is one of the main contributors to the introduction of invasive 
Sustainability, Agri, Food and Environmental Research, (ISSN: 0719-3726), 10(X), 2022: http://dx.doi.org/

species into sensitive ecosystems as recognized by the International Maritime Organization (IMO). The increase in fuel consumption as a result of fouling of the hull of the ship leads to serious environmental problems, such as the increase of emissions of greenhouse gases ( $\mathrm{CO} 2, \mathrm{SOx}$ and $\mathrm{NOx}$ ) to the atmosphere, and resultant the increase in precipitation of acid rain that, which, in turn, lowers the $\mathrm{pH}$ of the oceans affecting marine life.

\section{EFFECT OF THE INVASIVE AQUATIC SPECIES}

The introduction of invasive species into a new environment can have serious consequences for the environment and local biodiversity, economic consequences for industries and users of natural resources. In general, the effects of invasive species can be divided into Ecological and Economic categories:

i) Ecological Impact

Invasive organisms can modify ecosystems by displacing endemic organisms or becoming pest organisms in the region. Another effect of IAS is the pathogenic microorganisms that could cause diseases to the macro-organisms of other areas by decreasing their population and modifying the surrounding. Although the initial impacts may be minor and almost invisible, as the invasive population increases over time, the impacts will increase in severity. Another environmental impact produced by invasive aquatic species is the competition with native species for space and food and the potential extermination of the latter. All these cause the displacement of the native species, which reduces biodiversity and, in some cases, causes the extinction of local species.

ii) Economic Impact

The introduction of invasive aquatic species in new ecosystems produces a strong economic impact due to reduced productivity, as well as the costs incurred for the prevention and management of invasive species. Specific examples of the economic impacts of IAS are:

a) Reductions in fishing production due to competition, predation or displacement of fishing species by invasive species, and/or by habitat changes caused by invading species.

b) Impacts on the aquaculture industry, which include the closure of many local facilities, especially when affected by dangerous algal blooms.

c) Physical impacts on infrastructure, facilities, and coastal industries, which are affected by corrosion and by species like the zebra mussel.

d) Closure of recreational and other coastal tourist sites due to invasive species.

e) Costs associated with public health to treat introduced pathogens and toxic species. 
Sustainability, Agri, Food and Environmental Research, (ISSN: 0719-3726), 10(X), 2022: http://dx.doi.org/

\section{IMPACT OF BIOFOULING ON SHIP RESISTANCE}

Ships are normally exposed to different types of resistance affecting their efficiency; however, the three main factors increasing ship resistance are the form or shape of the vessel, wave making resistance, and frictional resistance. The frictional resistance is caused by fouling on ships' hulls. Fouling has a significant impact on ship's performance and efficiency because it increases the ship's hydrodynamic volume, which could increase the drag. This causes a reduction of the ship speed and increased fuel consumption in order to maintain the required speed. Moreover, experimental studies had been carried out providing valuable information on the impact of roughness on frictional resistance.

\section{ANTI-FOULING AND ITS IMPACT ON MARINE ENVIRONMENT}

Anti-fouling systems are the remedy to the increasing problem of biofouling (Alghamdi S, 2019). IMO defines such systems as: "A coating, paint, surface treatment, surface or device that is used on a ship to control or prevent attachment of unwanted organisms". Namely, Antifouling paints are applied on the hull of a ship, reducing the accumulation of invasive aquatic species, maintaining a smooth hull. However, along with ensuring a smooth hull, antifouling also protects the marine environment.

This technology is not new. Even from the early days of sailing ships, lime and later arsenic were used to coat their hulls. Then, modern chemical industry created effective antifouling paints using metallic compounds. These compounds slowly enter into the sea water, killing barnacles and other marine life that are attached to the ship. However, studies have shown that these compounds remain in the water, killing marine organisms and damaging the environment.

Nowadays, most AF paints are releasing toxins. This ensures a decent antifouling performance, but it may harm the marine environment. Because of this, the use of organotin, such as tributyltin (TBT), on ship hulls was banned in 2001, while other toxins in antifouling are restricted by law. Furthermore, copper-based paints are not yet prohibited, but they may be in the future. This has led the industry to come up with alternative solutions to prevent invasive species from sticking in ships' hulls. Some of them are:
a) Hydrophobic foul-release coatings
b) Copper-free antifouling
c) Nano antifouling 
Sustainability, Agri, Food and Environmental Research, (ISSN: 0719-3726), 10(X), 2022: http://dx.doi.org/

Tributyltin or TBT is a biocide which came into being in the $1970 \mathrm{~s}^{\prime}$ because of its brilliant anti-fouling properties over ship's hull as it prevents the growth of algae, barnacles and other marine organisms. But later it was found that TBT is one of the most dangerous and controversial contaminants that ever existed.

TBT causes alterations in the endocrine system of marine molluscs and causes the development of male characters in female snail (Santillo D, 2002). This biocide also damages the immune system, and even very low exposures in molluscs are responsible for malformations in the shell. Chemicals from the paint spread into the surrounding seawater and accumulate in sediments around harbours and along shipping lanes. TBT is widely dispersed throughout the oceans by means of marine navigation and has been found in the tissues of cetaceans, seals, sea otters, and seabirds throughout the world. Tissue and sediment samples from areas with intense navigation activity show the highest concentrations of contamination. As for the toxicity in the marine environment of TBT, it can cause both fatal and lethal damage in different species, causing biochemical alterations to local extinctions. TBT can cause harmful effects in extremely low concentrations in the most sensitive groups, such as Phytozooplankton and oysters, below 1 ppt, a concentration that is easy to reach in real situations, even in areas away from emission sources. In the sediment, TBT can persist for years, even decades, representing a long-term contaminant deposit that can pose serious problems.

The shipping industry cannot have barnacles, mussels and other organisms sticking to the hulls of vessels and offshore structures. So, continuing to use TBT based products will only cause harm to the marine environment. An alternative paint is the best solution for this worldwide problem. As the rules of IMO regarding anti-fouling paints become stringent day after day, the paints have become more environment friendly with least effect on the marine environment.

INTERNATIONAL CONVENTION ON THE CONTROL OF HARMFUL ANTI-FOULING SYSTEMS ON SHIPS - THE AFS CONVENTION

As a result of the different initiatives created for the prohibition of TBT, the International Maritime Organization drew up the "International Convention on the Control of Harmful Antifouling Systems on Ships" (AFS Convention), adopted on October 5, 2001, and which entered into force internationally on September 17, 2008, one year after it was ratified by a minimum of 25 States whose combined merchant fleets represented almost $38.1 \%$ of the gross tonnage of the merchant marine world. The purpose of the convention is to reduce or eliminate the unfavourable effects of some AF system, widely used as a biocide in ship hull protection paints (IMO-AFS Convention, 2008). 
Sustainability, Agri, Food and Environmental Research, (ISSN: 0719-3726), 10(X), 2022: http://dx.doi.org/

Under the terms of the AFS Convention, Parties to the Convention are required to prohibit and/or restrict the use of harmful anti-fouling systems on ships flying their flag, as well as ships not entitled to fly their flag but which operate under their authority and all ships that enter a port, shipyard or offshore terminal of a party. The AFS Convention benefits both the states parties and the shipping industry, while helping to care for the marine environment and the health of people by controlling the toxic substances found in antifouling paint.

\section{CONCLUSIONS AND RECOMMENDATIONS}

There are alternative products available to replace TBT, a few of which contain other biocides that can be nearly as toxic (Hellio. C, 2009). Before tributyltin was introduced in the early 1970's, the most commonly used antifouling paint was copper based. After the ban on TBT, many have turned back to these copper paints, although copper is recognized as a harmful toxin, especially in the marine environment, where it causes severe respiratory problems, among other things.

One of the alternatives is a biocide free system called the Foul Releasing System (FR system) or "non-stick" system. After application, the hull of a ship becomes too slippery for algae, barnacles, and other marine life to attach themselves to the surface. Such coatings have been commercially available for many years and retain a significant market for leisure craft. Their viability and performance on larger vessels remain under evaluation, although applicability for fast-moving craft has been demonstrated. However, these are clearly unlikely to be very effective for stationary vessels and other submerged structures.

At present, no Antifouling paints available which completely resist biofouling. The only solution is a thorough and efficient ship hull cleaning along with the use of a suitable hull coating. Other than the usage of Antifouling paints, various other techniques are currently being used to remove fouling (Song. C., Cui. W., 2020). There are two main choices for cleaning: dry-dock cleaning and afloat under water cleaning (Hydrex- The Maritime Executive, 2011). Dry-dock cleaning requires the ship to be dry docked, and is very expensive in terms of resources and curtailment of ship operational schedules. High pressure water jet using manual gun systems is used for removal of the fouling. They also make use of rotating nozzles to clean large areas of the hull.

Afloat under water cleaning requires specially trained and experienced divers, selfpropelled devices with rotating tools or scrapers which are maintained in contact with hull by suction, steered by a diver and other tools to clean niche areas. Belgium bases Hydrex Group which has a large team of trained and experienced divers are pioneers in this field (HydrexThe Maritime Executive, 2011). Cleaning of underwater hull is more effective while the ship is 
Sustainability, Agri, Food and Environmental Research, (ISSN: 0719-3726), 10(X), 2022: http://dx.doi.org/

away from the quayside as this provides easier access to both vertical sides and the flat bottom and the divers can work freely around the ship, thus speeding up the operation.

There are circumstances where diving conditions are unpredictable, which would require unmanned operations. Currently there are two choices under consideration (Jones D, 1999). One is to use a remotely operated vehicle (ROV) for underwater hull cleaning. ROVs are already being used in the maritime industry for other purposes. The other choice is to build a large installation which would operate like a floating dock by submerging beneath the ship to be cleaned and then travelling along the hull using an array of brushes to remove the fouling.

Another alternative is automatic high-pressure water cleaning jets, used while the ship is afloat. This method relies on its own impact force of water jets to remove biofouling on the hull. A high working pressure corresponds to a good cleaning effect. The Hull Wiper (https://www.hullwiper.co/) cleans the hull, collects debris removed directly, without discharging it locally to avoid pollution and species spreading. Hull Wiper takes local water as a medium for hull cleaning and sprays high-pressure water up to 50-450 bar on the hull, to remove biofouling.

Cavitating water jet technology is an improved version of high-pressure water cleaning technology that uses specially designed nozzles to induce cavitation which enhances the cleaning of the hull. The extent of cavitation water can be varied by modifying the nozzle design. The bubbles rupture as they approach the hull, resulting in very high local pressure which can result in greater extent of cleaning. This feature is a significant advantage of conventional high-pressure water jets which operates at the same pressure. Many companies have developed jet nozzles and cleaning devices/systems based on cavitation water jet technology to enable underwater cleaning efficiency.

Antifouling solutions depend on external factors such as of dry-docking intervals, ship speed, area of operations and the type of fouling. While the trend is towards biocide-free products, their performance is linked to ships' speed and shows poor results at low speed or in case of long periods of inactivity. Some new technologies promise high effectiveness; however, their high cost may restrict their use.

Finally, the type of Anti-Fouling system (AFS) chosen depends on the characteristics of the ship and its areas of operation. Extensive research and studies are in progress to find a perfect solution to replace TBT, which hopefully would materialise in the near future itself.

\section{REFERENCES}

AFS Convention, (2008), "Focus on IMO- Anti- Fouling Systems"https://wwwcdn.imo.org/localresources/en/OurWork/Environment/Documents/FOULI NG2003.pdf 
Sustainability, Agri, Food and Environmental Research, (ISSN: 0719-3726), 10(X), 2022:

http://dx.doi.org/

Alghamdi. S., Quijada. R., (2019), "The Impact of Biofouling on Marine Environment: A QualitativeReviewoftheCurrentAntifoulingTechnologies".

Amaraa. I., Mileda. W., Slamab. R., Ladharic. N., (2017), "Antifouling processes and toxicity effects of antifouling paints on marine environment: A review".

Hellio. C. Yebra. D (Ed), (2009), "Advances in Marine Antifouling and Technologies"; Woodhead Publishing, Cambridge.

https://safety4sea.com/cm-understanding-marine-biofouling-how-anti-fouling-systemsprevent-growth/

https://www.hullwiper.co/

Hydrex's Practical Guide to Industrial Underwater Ship Hull Cleaning (2011) - "Underwater ship hull cleaning: cost-effective, non-toxic fouling control" - The Maritime Executive.

Jones D., (1999), "Controlling Marine Fouling with Antifouling Paints and Underwater Hull Cleaning"; UMC International.

Milne. A. (1990), "Roughness and Drag from the Marine Paint Chemist's Viewpoint," presentation at an International Workshop on Marine Roughness and Drag, Royal Institution of Naval Architects, London.

Qureshi. A., Dr. Ramaswamy R. (1990), "Evolution of Antifouling Paints", International Journal of Science and Research, Vol 6 (10).

Santillo D, Johnston P and Langston W. (2002), "Tributyltin (TBT) antifoulants: a tale of ships, snails and imposex".

Song. C., Cui. W. (2020), "Review of underwater ship hull cleaning technologies"; Journal of Marine Science and Application.

Thomas. K., Brooks. S. (2010), "The environmental fate and effects of antifouling paint biocides".

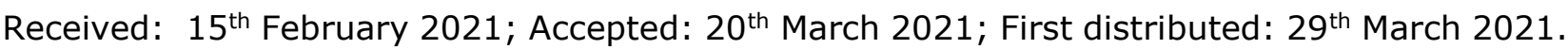

